Int. J. Dev. Biol. 48: 845-856 (2004)

doi: $10.1387 / \mathrm{ijdb} .041869 \mathrm{db}$

\title{
Contributions by members of the TGFbeta superfamily to lens development
}

\author{
DAVID BEEBE ${ }^{*}, 1,2$, CLAUDIA GARCIA ${ }^{1}$, XIAOHUI WANG $^{1}$, RAMYA RAJAGOPAL ${ }^{1}$, MARY FELDMEIER ${ }^{1}$, \\ JI-YOUNG KIM ${ }^{1}$, ANNA CHYTIL ${ }^{3}$, HAROLD MOSES ${ }^{3}$, RUTH ASHERY-PADAN ${ }^{4}$, and MICHAEL RAUCHMAN ${ }^{5}$ \\ ${ }^{1}$ Dept. Ophthalmology and Visual Sciences, ${ }^{2}$ Dept. Cell Biology and Physiology, Washington University, St. Louis, MO, USA, ${ }^{3}$ Dept. \\ Cancer Biology, Vanderbilt University, Nashville, TN, USA, ${ }^{4}$ Dept. Human Genetics and Molecular Medicine, Tel-Aviv University, Ramat \\ Aviv, Israel and ${ }^{5}$ Dept. Biochemistry, St. Louis University, St. Louis, MO, USA
}

\begin{abstract}
Members of the TGF $\beta$ superfamily of growth and differentiation factors, including the TGF $\beta$, BMP, activin and nodal families, play important signaling roles throughout development. This paper summarizes some of the functions of these ligands in lens development. Targeted deletion of the genes encoding one of the BMP receptors, Alk3 (BMP receptor-1A), showed that signaling through this receptor is essential for normal lens development. Lenses lacking Alk3 were smaller than normal, with thin epithelial layers. The fiber cells of Alk 3 null lenses became vacuolated and degenerated within the first week after birth. Lenses lacking Alk 3 function were surrounded by abnormal mesenchymal cells, suggesting that the lenses provided inappropriate signals to surrounding tissues. Lens epithelial and fiber cells contained endosomes that were associated with activated (phosphorylated) SMAD1 and SMAD2. Endosomal localization of pSMAD1 was reduced in the absence of Alk3 signaling. The presence of pSMAD2 in lens fiber cell nuclei and the observation that the activin antagonist follistatin inhibited lens cell elongation suggested that an activin-like molecule participates in lens fiber cell differentiation. Lenses deficient in type II TGF $\beta$ receptors were clear and had fiber cells of normal morphology. This suggests that TGF $\beta$ signaling is not essential for the normal differentiation of lens fiber cells. The targeted deletion of single or multiple receptors of the TGF $\beta$ superfamily in the lens should further characterize the role of these signaling molecules in lens development. This approach may also provide a useful way to define the downstream pathways that are activated by these receptors during the development of the lens and other tissues.
\end{abstract}

KEY WORDS: lens, TGF $\beta$ superfamily, bone morphogenetic proteins, endosomes, differentiation

\section{Introduction}

Members of the transforming growth factor- $\beta$ (TGF $\beta$ ) superfamily play important roles in regulating the specification, differentiation, proliferation and survival of cells in vertebrate and invertebrate embryos (Chang et al., 2002a, Mishina 2003, Patterson and Padgett 2000). The TGF $\beta$ superfamily includes members of the TGF $\beta$, activin, bone morphogenetic protein (BMP) and nodal families, as well as several other related ligands (inhibin, myostatin, Mullerian inhibiting substance and others). These ligands are proteolytically processed from inactive precursors, secreted as homo- or heterodimers and bind to a family of transmembrane receptor serine/threonine kinases on target cells (type II receptors). The ability of TGF $\beta$ superfamily ligands to interact with their receptors is modulated by co-receptors and numerous extracellular binding proteins that can inhibit or promote signaling (Smith 1999). Type II receptors transduce signals by phosphorylating and activating type I receptors, leading to the phosphorylation of cytoplasmic proteins, called SMADs (Fig. 1). Type I receptors also activate SMAD-independent intracellular signaling pathways (Derynck and Zhang 2003). The effects of signaling through SMAD-dependent and -independent pathways are mediated by a growing number of transcriptional activators and inhibitors. However, relatively little is known about the networks of genes that are controlled by TGF $\beta$ superfamily members in specific cell lineages in the embryo.

Abbreviations used in this paper: BMP, bone morphogenetic protein; TGF, transforming growth factor.

\footnotetext{
*Address correspondence to: David C. Beebe, PhD. Dept. Ophthalmology and Visual Sciences, Campus Box 8096, 660 S. Euclid Ave. Washington University, St. Louis, MO 63110. Fax: +1-314-747-1405. e-mail: beebe@wustl.edu
} 
TGF $\beta$ superfamily ligands, receptors and their binding proteins are present and play important roles in eye development (BeleckyAdams and Adler 2001, Belecky-Adams et al., 1999, de longh et al., 2001a, Obata etal., 1999, Sakuta etal., 2001, Yoshikawa etal., 2000). Germ line deletion of at least two ligands, BMP4 and BMP7, showed that they participate in lens induction and later eye development (Furuta and Hogan 1998, Jena etal., 1997, Luo et al., 1995, Solursh et al., 1996, Wawersik et al., 1999). There is also evidence that BMPs and TGF $\beta$ s contribute to the later differentiation of lens fiber cells (Belecky-Adams et al., 2002, de longh et al., 2001b, Faber et al., 2002), the proper differentiation of the ciliary epithelium (Zhao et al., 2002), the differentiation of the ventral region of the optic cup (Adler and Belecky-Adams 2002), cell survival and axon guidance in the retina (Liu et al., 2003, Trousse et al., 2001), the differentiation of the retinal pigmented epithelium (Fuhrmann etal., 2000) and the formation of the corneal endothelium and stroma (Saika etal., 2001, Sanford etal., 1997). Unfortunately, germ line deletion of the genes for receptors in the TGF $\beta$ superfamily often results in early embryonic lethality (Goumans and Mummery 2000), limiting studies of the role of these receptors in eye development.

The simplicity of lens organization, the many tools that are available for modifying gene expression in the living lens and the fact that proper development of the eye and lens is not required for viability suggest that it may provide a useful system in which to learn how TGF $\beta$ superfamily members regulate development in vivo. The lens is composed of two types of epithelial cells that exist in distinct compartments; the epithelium and the fiber mass (Fig. 2). The lens epithelium, a sheet of cuboidal epithelial cells, covers the anterior surface of the lens. The fiber mass, which makes up the bulk of the lens, is formed from elongated, terminally differentiated fiber cells. A thick extracellular matrix, the lens capsule, surrounds the lens. Cell proliferation is normally restricted to the epithelial compartment. Early in development, mitosis occurs throughout the epithelium. Cell division gradually becomes restricted to epithelial cells near the lens equator. When the equatorial epithelial cells divide, daughter cell pairs move posteriorly (Rafferty and Rafferty

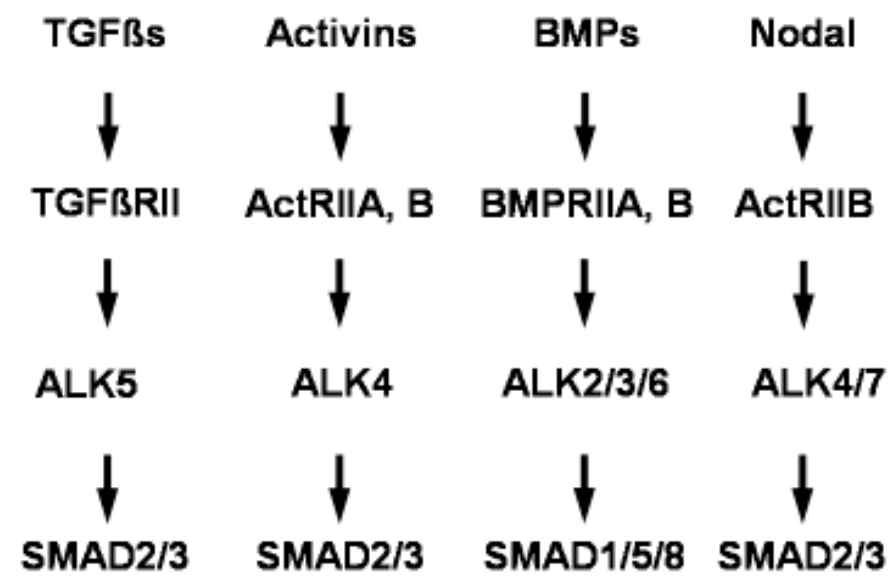

Fig. 1. Diagram outlining the major signaling pathways used by members of the TGF $\beta$ superfamily. The first row contains the ligands, the second row the type II receptors to which these ligands bind, the third row the type I receptors, and the fourth row the intracellular SMADs that are phosphorylated by the type I receptors.
1981), withdraw from the cell cycle (Zwaan and Kenyon 1984) and differentiate into fiber cells (Fig. 2). Fiber cells elongate greatly (Bassnett and Winzenburger 2003) and synthesize and accumulate large amounts of a limited number of cytoplasmic proteins, the crystallins. Crystallin accumulation in the fiber cells is essential for the transparency and high refractive index of the lens (Benedek et al., 1999, Delaye and Tardieu 1983). Fiber cells also synthesize a distinct set of abundant membrane proteins that endow the fibers with specialized transport properties (Goodenough 1992, Kushmerick et al., 1995, Merriman-Smith et al., 1999). Fiber cell elongation ceases when the apical and basal ends of the elongating cells reach the midpoint of the lens (Bassnett and Winzenburger 2003). There they meet elongating fibers from the other side of the lens at specialized interfaces called sutures (Kuszak 1995). Suture formation is accompanied by detachment of the posterior (basal) end of the fiber cells from the lens capsule (Fig. 2). The continued formation of successive waves of fiber cells causes cells that have detached from the capsule to be buried deeper within the lens. Soon after the fiber cells detach from the capsule, they alter their cell-cell adhesions (Bassnett and Winzenburger 2003, Beebe et al., 2001), activate the expression of a new set of genes (Vasiliev, Rhodes and Beebe, submitted), partially fuse with their neighbors (Shestopalov and Bassnett 2000), and then degrade all intracellular membrane-bound organelles, including the nucleus (Bassnett 2002, Bassnett and Beebe 1992, Kuwabara and Imaizumi 1974). These mature fiber cells persist in the lens for the life of the individual.

Several characteristics of the lens make it particularly suitable for studying growth factor signaling. Analysis of tissue interactions is simplified, because the lens has no connective tissues, nerves or vascular supply and the capsule separates lens cells from contact with other cell types. Sheets of epithelial cells, still attached to the capsule, can be placed in culture and used to determine the ability of purified growth factors to regulate epithelial cell proliferation or fiber cell differentiation (Beebe et al., 1987, Chamberlain and Mcavoy 1989). In addition, tissue-specific promoters are available that allow genes encoding growth factors, their receptors, or binding proteins to be over expressed in the epithelial or fiber cells of the lenses of transgenic animals (Chow et al., 1995, Faber et al., 2001, Reneker etal., 1995, Robinson etal., 1995a, Robinson etal., 1995b). Recently, transgenic mice have been produced that express Cre recombinase in lens cells, enabling the selective inactivation of genes using Cre-loxP gene targeting (Ashery-Padan et al., 2000, Macpherson et al., 2003). Because germ line deletion of the genes encoding growth factors or their receptors often disrupts early embryogenesis, the selective deletion of genes in the lens provides a powerful tool to study the contribution to lens development of individual components of a growth factor signaling pathway. Comparison of the transcripts expressed in wild type and receptordepleted lenses should permit the identification of genes that are directly and indirectly regulated by growth factor signaling in the lens.

We are using Cre-mediated gene targeting to define the contribution of members of the TGF $\beta$ superfamily to lens development. Our initial studies reveal that one of the type I BMP receptors, Alk3 (BMPR-1A), is important for normal lens development. We also found evidence that an activin-like molecule contributes to lens fiber cell differentiation. This led us to examine of the distribution of phosphorylated SMAD1 and SMAD2 in lens 


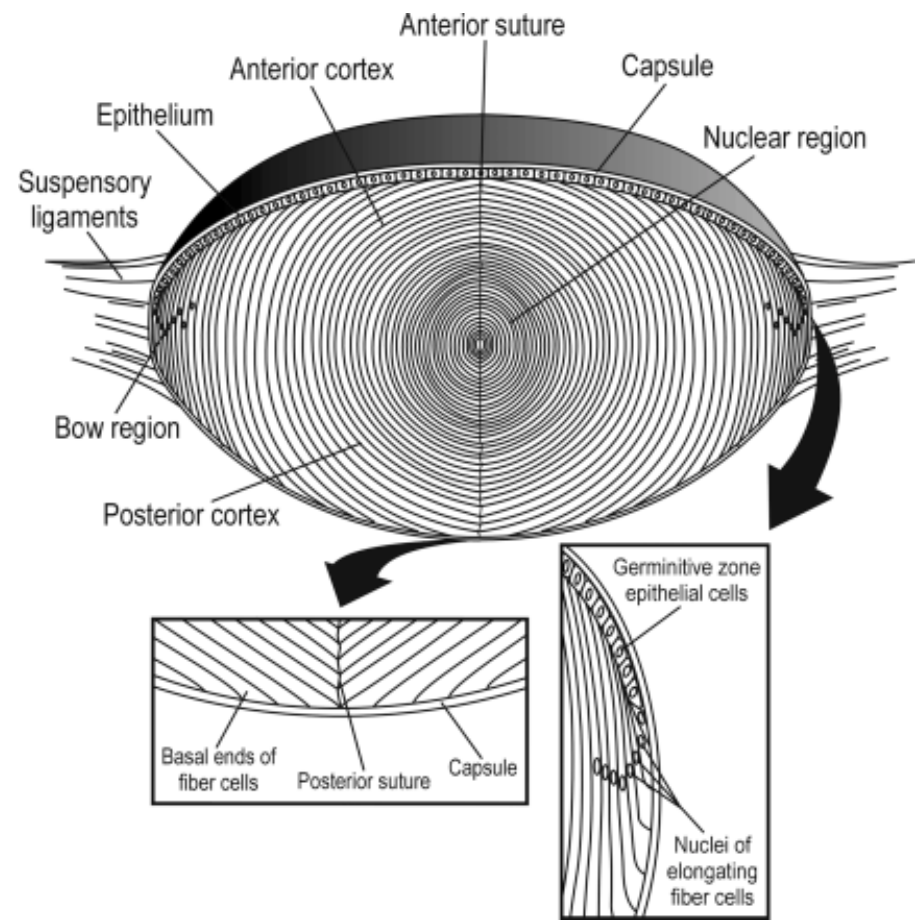

Fig. 2. Diagram showing the cellular structure of the vertebrate lens. The boxes illustrate the cellular arrangements at the posterior lens sutures and the lens equator. Diagram is from Adler's Physiology of the Eye (P. Kaufman and A. Alm, Eds.) Mosby, St. Louis, MO., used with the permission of the publisher.

cells, which revealed that these activated SMADs are present on endosomes in the lens epithelial and fiber cells. Since endosome formation is required for signaling by TGF $\beta$ (Hayes et al., 2002, Panopoulou et al., 2002), our results raise the possibility that signals from activin and BMP receptors also depend on the formation of endosomes. Finally, we were surprised to find that lenses in which the type II TGF $\beta$ receptor had been deleted appeared normal, since a previous study (de longh et al., 2001b), found that over expression of dominant-negative type II and type I TGF $\beta$ receptors interfered with normal fiber cell differentiation. Our studies suggest that targeted gene deletion in the lens will provide a valuable tool to analyze the cellular and molecular consequence of signaling by members of the TGF $\beta$ superfamily during development.

\section{Results}

BMPs play important roles in lens induction (Furuta and Hogan 1998, Jena et al., 1997, Luo et al., 1995, Solursh et al., 1996, Wawersik et al., 1999) and in the differentiation of lens fiber cells (Belecky-Adams et al., 2002, Faber et al., 2002). To learn more about the function of BMP signaling during lens development, we examined mice in which one of the type I BMP receptors was selectively deleted in the lens using Cre-loxP-mediated gene targeting.

\section{Targeted deletion of Alk3 (BMPR1A)}

$A / k 3$ is the most abundant type I BMP receptor in the tissues that give rise to the eye and is, therefore, likely to mediate, at least in part, the effects of BMP signaling during lens development (Furuta and Hogan 1998). Embryos homozygous for a germ line deletion of $A / k 3$ arrest at gastrulation (Mishina et al., 1995). Therefore, we examined the offspring of $A / k 3^{\text {flox/flox }}$ mice (Mishina et al., 2002) that also expressed a Cre transgene under control of the Pax6 P0 promoter. In these mice, Cre is expressed in the head ectoderm and lens placode by E9.0 (Ashery-Padan et al., 2000). Mice that were homozygous for the floxed allele would be expected to lack functional Alk3 in the lens and ocular surface epithelia (Ashery-Padan et al., 2000, Walther and Gruss 1991).

Mice that were $A / k 3^{\text {flox }}$ /lox and that expressed the Cre transgene $\left(\mathrm{Cre}^{+}\right)$had no eyelashes and lacked hair on the surface of the eye lids and in a stripe that ran from the temporal to the nasal side of the eye (Fig. 3). Other than the absence of hair, the lids and ocular surface epithelia appeared normal by gross inspection at eye opening. The corneal opacity in the eye shown in Fig. 3 is likely to be the result of corneal irritation and infection, due to the lack of eyelashes. BMP signaling is known to be essential for the formation of normal hair shafts and Alk 3 is prominently expressed in the hair anlagen (Botchkarev et al., 2001, Kulessa et al., 2000). The

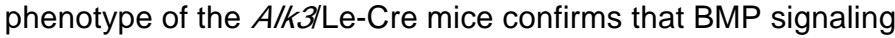
is required for hair shaft formation and that $A l k 3$ mediates BMP signaling in the hair follicle. A recent study found similar effects on hair formation after targeted deletion of $A / k 3$ in the skin (Kobielak et al., 2003).

Targeted deletion of genomic regions flanked by loxP sites are detected in Le-Cre+ embryos by E9.5 (Ashery-Padan etal., 2000). Examination of embryos at $\mathrm{E} 13.5$ showed that the lenses of $A / \mathrm{k} 3$ floxfflox, $\mathrm{Cre}^{+}$embryos were present, but smaller than in $\mathrm{Cre}^{-}$ embryos, with attenuated lens epithelia. Other than these differences, the overall structure of the lens appeared normal at this stage (Fig. 4 A,B). The eye was smaller and the retinal layer thicker than in Cre-embryos, as would be expected for an eye with a smaller lens, since the lens makes up a significant proportion of the volume of the eye. In $\mathrm{Cre}^{+}$embryos, the blood vessels posterior to the lens, the hyaloid artery and the capillaries of the tunica vasculosa lentis (TVL), were surrounded by a dense mass

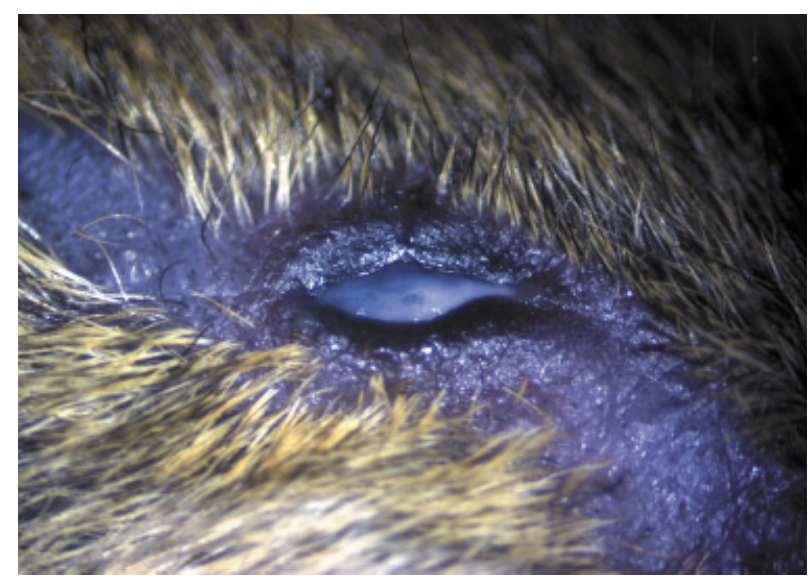

Fig. 3. Appearance of the side of the head of an adult $A / k 3^{\text {flox/flox }}$ mouse that was Le-Cre+. Hair and eyelashes were absent in a stripe that ran from the temporal to the nasal side of the eye. The corneal opacity is due to inflammation and infection of the eye, presumably secondary to the loss of eyelashes. 

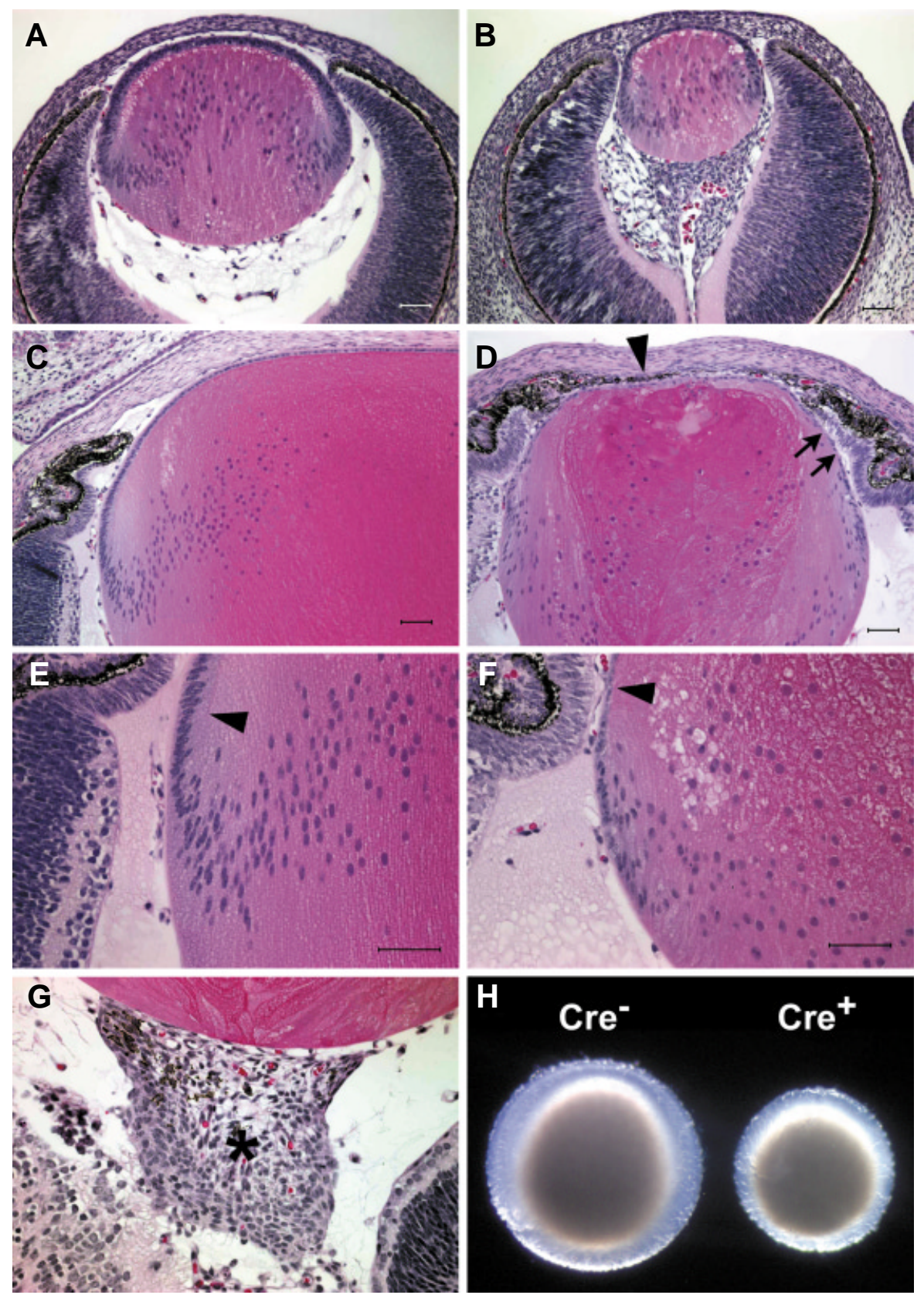

Fig. 4. Sections through the eyes of $A / \mathbf{k}^{\text {flox/flox }}$ animals with or without the expression of Cre recombinase in the lens and ocular surface epithelia. (A) A Cre- E13.5 embryo showing

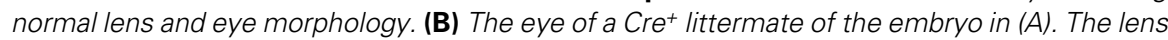
and eye are reduced in size, there is an increase in mesenchymal cells in the vitreous and anterior chambers and the retina is increased in thickness. (C) A section through a portion of a Cre- lens in the eye of a P2 mouse showing normal eye and lens morphology. (D) A section of a Cre ${ }^{+}$lens of a littermate of the animal shown in (C). The lens is smaller, the fiber cells are disorganized and their nuclei are displaced toward the posterior of the lens. The lens epithelium is thinner than normal and is discontinuous in some areas (arrows). Pigmented cells partially fill the space that would normally be the anterior chamber (arrowhead). (E) A higher magnification view of a P2, Creeye showing the equatorial region of the lens. The arrowhead indicates the normal thickness of the lens epithelium in this region. (F) The equatorial region of a Cre+ lens from a P2 animal. The lens epithelium is markedly thinner than normal (arrowhead), the nuclei of the lens fibers are displaced toward the posterior of the lens and the cortical fiber cells are vacuolated. (G) Section of a P2, Cre+ lens showing the mass of cells attached to the posterior capsule (asterisk). (H) P2 lenses dissected from the eye to show the difference in size. The nuclear opacity is a "cold cataract" and is typical of lenses of this age. of cells that filled about half of the volume of the vitreous body. The remainder of the vitreous body was also more cellular than in the Cre- eyes. The identity of these abnormal cells remains to be determined. There was also an increase in the number of cells anterior to the lens, adjacent to the lens epithelium, filling the space that would normally have been the anterior chamber of the eye. The differentiation of the corneal endothelium also appeared to be delayed or defective. In a few eyes, the lens and corneal epithelium failed to separate. In these cases, the "lens stalk" connecting these tissues could still be seen postnatally (see Fig. 5B).

At birth, the lenses of $A / \mathrm{k}^{\text {flox/flox }}, \mathrm{Cre}^{+}$mice continued to be smaller than their Cre- littermates (Fig. $4 \mathrm{C}, \mathrm{D}, \mathrm{H}$ ). The lens epithelium was attenuated and defects were evident in the fiber cells. The difference in the thickness of the lens epithelium in the $\mathrm{Cre}^{-}$and $\mathrm{Cre}^{+}$lenses could best be appreciated near the lens equator, where the epithelium is normally thicker (Fig. 4 $E, F)$. In many of the $\mathrm{Cre}^{+}$lenses, the epithelial layer was discontinuous in this region (Fig. 4D). The fiber cell nuclei were displaced posterior to their normal location and many of the fiber cells were vacuolated (Fig. $4 \mathrm{C}-\mathrm{F}$ ), suggesting abnormalities in fiber cell elongation and differentiation. Normal fiber cell denucleation did occur in the $\mathrm{Cre}^{+}$lenses (Fig. 4D). In preliminary studies of two $\mathrm{Cre}^{-}$and two $\mathrm{Cre}^{+}$ lenses, the BrdU labeling index was approximately $25 \%$ lower in the $\mathrm{Cre}^{+}$than in the Cre- lenses. Further studies are needed to determine whether this difference is statistically significant and whether it accounts for the diminished number of epithelial cells and the smaller size of the lens.

There were also abnormalities in the tissues around the lens in neonatal $A / \mathrm{k}^{\text {flox/flox, }} \mathrm{Cre}^{+}$ animals. The anterior chamber was filled with cells, many of which were pigmented (Fig. 4 C,D) and no anterior chamber angle could be discerned. It was difficult to determine whether the corneal endothelium was present, due to the cells in the anterior chamber. The tissue surrounding the hyaloid vasculature at E13.5 had condensed into a dense mass and many of the cells within it were now pigmented (Fig. $4 \mathrm{G})$. The remainder of the vitreous body, which had been hypercellular at E13.5, no longer had an increased number of cells.

By postnatal day 9 (P9), the fiber cells of the $A / k 3^{\text {flox/flox }}$, $\mathrm{Cre}^{+}$mice had begun to degenerate (Fig. $5 \mathrm{~A}, \mathrm{~B}$ ). The fiber cells were disorganized and swollen and large vacuoles, filled with what appeared to be degenerating cytoplasm, were present in the fiber mass. In 
Fig. 5. Characteristics of $A / k 3^{\text {flox/flox }}$ lenses at P9. (A) Section through a Cre-P9lens stained with hematoxylin and eosin showing the normal structure of the lens, iris and anterior chamber. (B) Section through the eye of a $\mathrm{Cre}^{+}$littermate. The anterior of the lens is ruptured, extruding fiber cell cytoplasm (asterisks) between the abnormal mesenchymal cells that fill the anterior chamber. An arrow points to a portion of the lens stalk that, in adjacent sections was shown to connect the corneal epithelium and the lens. This defect is similar to "Peter's anomaly," a common anomaly in humans with anterior segment dysgenesis. The arrowat the posterior of the lens points to epithelial cells that have migrated to the posterior of the lens. A mass of cells is located between the retina and the posterior surface of the lens capsule. (C) Section of a Cre- lens stained for BrdU. BrdU labeling is seen in epithelial nuclei in the normal location adjacent to the ciliary epithelium. (D) BrdU staining of a Cre+ lens. Labeled epithelial cells are distributed in the anterior epithelium, in the abnormal epithelial cells at the posterior of the lens (arrow), and in the degenerating fiber mass (arrowhead).

some cases, the anterior capsule ruptured, allowing fiber cell cytoplasm to escape from the lens (Fig. 5B). Some of the fiber cells incorporated BrdU, while BrdU was never detected in the fiber cells of Cre- lenses. At P9, a layer of epithelial cells covered the posterior surface of the lens. Labeling with BrdU showed that these abnormally-located epithelial cells were synthesizing DNA. BrdU labeling could also be detected in the mass of cells posterior to the lens.
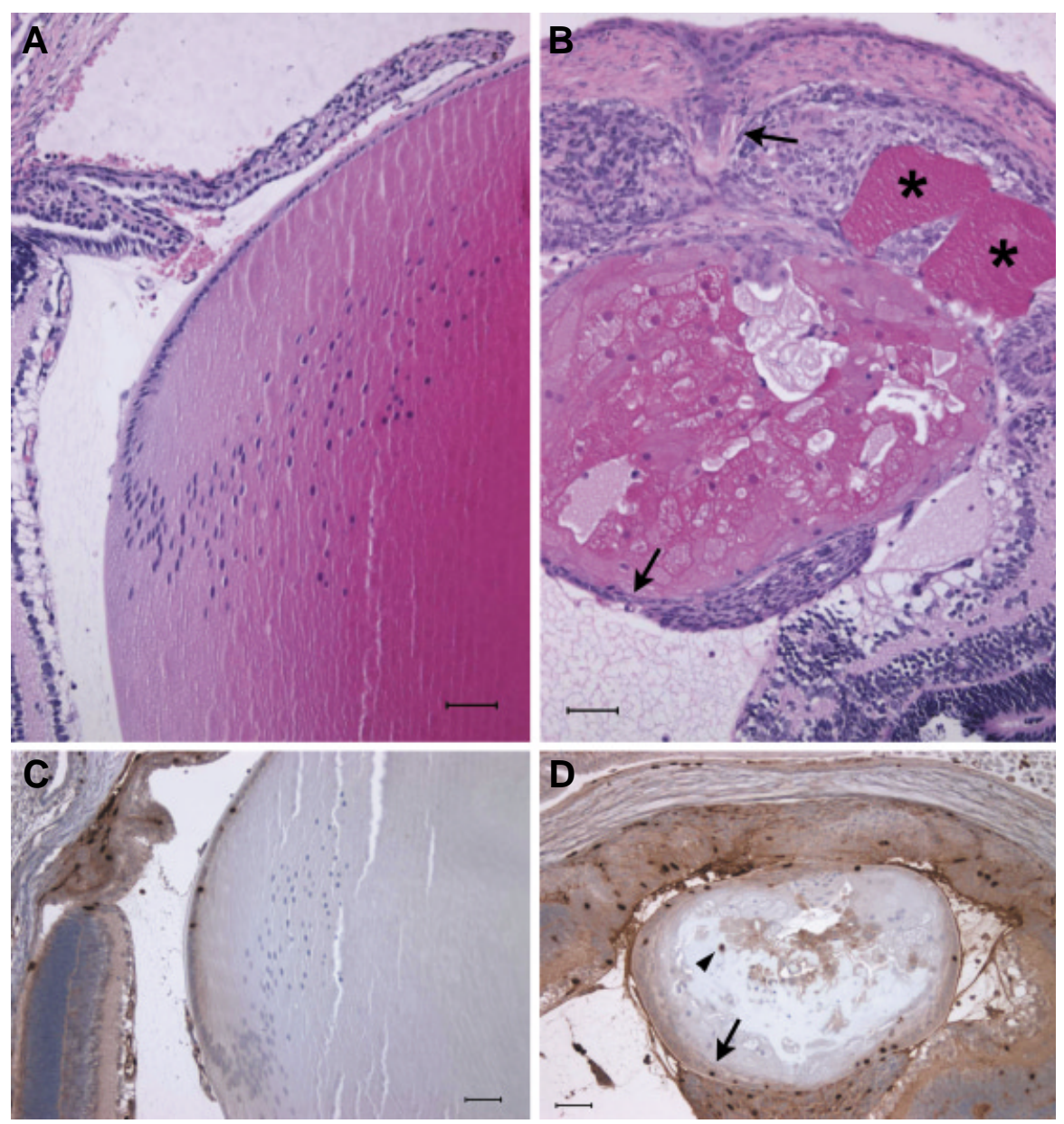

\section{Signaling by other members of the TGF $\beta$ superfamily during lens development}

Addition of the BMP antagonist noggin to cultured lens epithelial cells and primary lens fiber cells and over expression of noggin in the chicken embryo eye transiently inhibited lens fiber cell elongation (Belecky-Adams et al., 2002, Faber et al., 2002). We extended these studies by testing whether follistatin, a binding protein that preferentially inhibits members of the activin family, could alter the ability of vitreous humor to promote lens fiber cell elongation in explants of chicken embryo lens epithelia. Bovine vitreous humor was pre-treated with noggin, follistatin or equal amounts of both proteins, added to explants of E6 lens epithelia for five hours $(20 \% \mathrm{v} / \mathrm{v})$, and the extent of cell elongation was measured (Fig. 6). As in the previous study, noggin $(0.5 \mu \mathrm{g} / \mathrm{ml})$ partially inhibited lens epithelial cell elongation $\left(p<10^{-4}\right.$ compared to untreated vitreous humor). Increasing the concentration of noggin did not further inhibit elongation (not shown). Follistatin $(0.5 \mu \mathrm{g} / \mathrm{ml})$ had no effect on cell elongation. However, noggin and follistatin together completely prevented cell elongation $\left(p<10^{-5}\right.$, compared to the elongation seen with noggin alone). This result suggests that an activin-like activity in vitreous humor, together with BMPs, contributes to lens fiber cell differentiation.

Activins and BMPs signal through different type I receptors, leading to the phosphorylation of different sets of SMADs (Fig. 1). We previously found that phosphorylated SMAD1 (pSMAD1), a target of BMP signaling, localized to the nuclei of elongating lens fiber cells (Belecky-Adams et al., 2002). To test whether activinlike signaling occurred in vivo, we stained sections of E7 chicken lenses with antibodies to PSMAD1 and 2, since activin receptors signal through SMAD2. As described previously, antibodies to pSMAD1 strongly stained the nuclei of cells at the lens equator

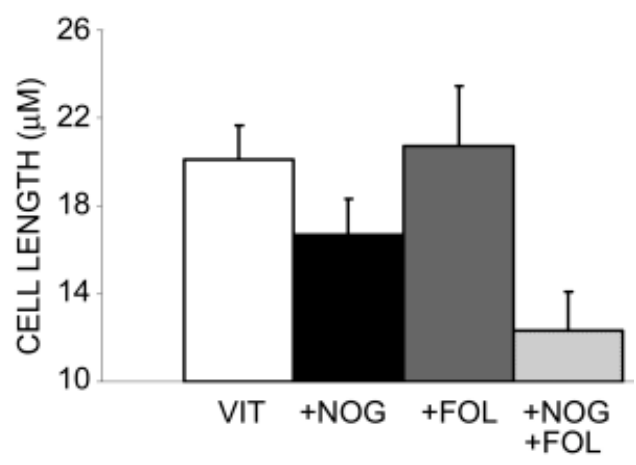

Fig. 6. Graph showing the extent of cell elongation after treating E6 chicken embryo lens epithelial explants with $20 \%$ bovine vitreous humor (vit). The vitreous humor was used untreated, or after pre-treatment with noggin (nog, $0.5 \mu \mathrm{g} / \mathrm{ml}$ ), follistatin (fol, $0.5 \mu \mathrm{g} / \mathrm{ml}$ ), or with both noggin and follistatin (each at $0.5 \mu \mathrm{g} / \mathrm{ml}$ ). 

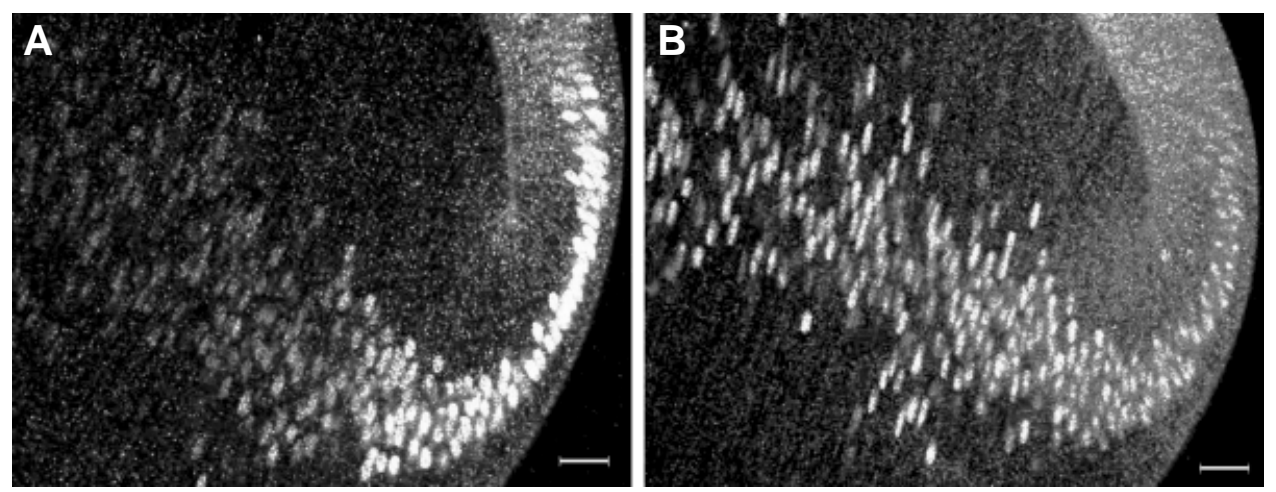

Fig. 7. SMAD staining in the lens. (A) Staining for PSMAD1 in sections of E7 chicken lenses. Nuclear pSMAD1 staining begins at the lens equator, is strongest during early fiber cell elongation, anddeclines laterin fibercellelongation. Small SMAD1-positive vesicles are present in the cytoplasm of epithelial and fiber cells. (B) Nuclear staining for pSMAD2 also begins at the lens equator. In the earliest fiber cells, staining is much weaker than for PSMAD1. However, nuclear staining for pSMAD2 persists throughout fiber cell elongation. pSMAD2-positive vesicles are present in the cytoplasm of both epithelial and fiber cells. Scale bars represent $25 \mu \mathrm{m}$.
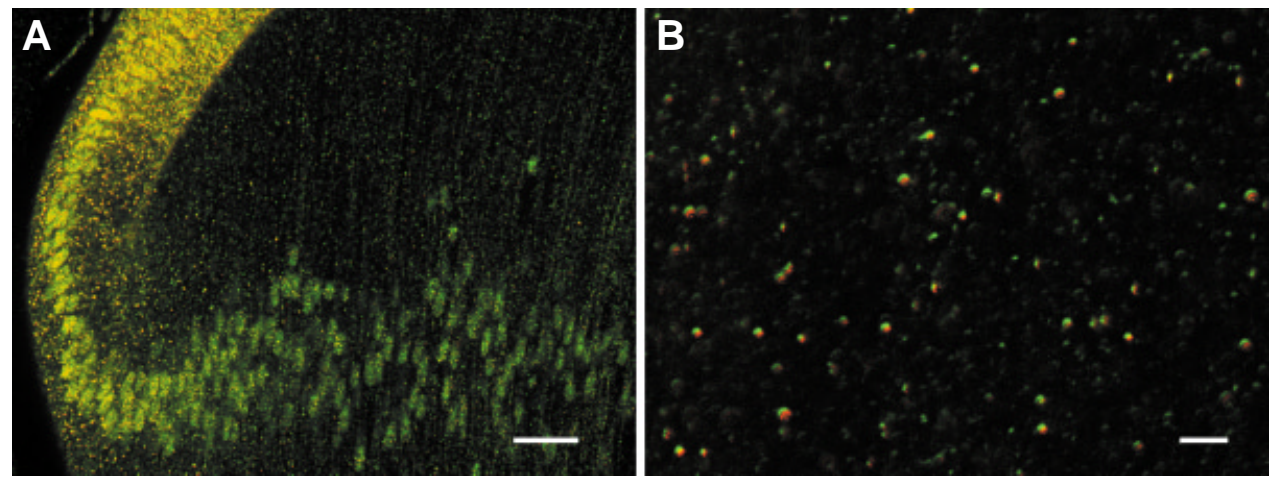

Fig. 8. The distribution of pSMAD1-2 staining in the lens. (A) A section of an E7 chicken lens stained with antibodies for pSMAD1 (red) and pSMAD2 (green). Staining co-localizes in the nuclei, showing the same distribution as in Fig. 7 , and in cytoplasmic vesicles (Scale bar is 25 $\mu \mathrm{m})$. (B) A higher magnification view of vesicles in the fiber cell cytoplasm stained as in (A). The alignment of the red and green channels has been shifted by 2 pixels, showing that nearly every vesicle is stained by both antibodies. Scale bar represents $10 \mu \mathrm{m}$.

that were just beginning the process of fiber cell elongation. Nuclear staining for PSMAD1 decreased soon after the initiation of fiber cell differentiation (Fig. 7A). Nuclear localization of pSMAD2 was also first seen at the initiation of fiber cell differentiation. However, in contrast to pSMAD1, the nuclei of cells at the lens equator were only weakly stained. The intensity of nuclear pSMAD2 staining increased as the fiber cells elongated and remained strong throughout later stages of fiber cell differentiation (Fig. 7B). These data show that SMAD2-dependent signaling occurs during fiber cell differentiation and are consistent with a role for an activin-like molecule in this process.

\section{pSMAD1 and -2 co-localize on endosomes}

We previously reported that antibodies to pSMAD1 stained small vesicle-like structures in the cytoplasm of epithelial and fiber cells (BeleckyAdams et al., 2002). In the present study we found that antibodies to pSMAD2 also stained vesicular structures in chicken embryo and newborn mouse lenses. We used double-label immunostaining to determine whether pSMAD1 and 2 co-localized to these structures. Since the antibodies to pSMAD1 and 2 were rabbit polyclonals, we modified our staining procedure to permit the co-localization of two primary antibodies raised in the same species. These procedures and the controls required to confirm the results obtained with them are described in the Methods section.

Antibodies to pSMAD1 and pSMAD2 co-localized to small vesicles in both epithelial and fiber cells of lenses from chicken embryos and newborn mice.
Figure 8 shows the distribution of these vesicles in the cells near the lens equator. Careful examination showed that nearly every vesicle profile stained for both SMADs, although the proportion of pSMAD1 and 2 staining varied in different vesicles.

To determine the nature of the pSMAD-positive vesicles, we stained lenses with antibodies to lysosome-associated membrane protein-1 (LAMP1), a lysosomal marker, or with antibodies to early endosome-associated antigen-1 (EEA1) or Rab5b, markers of early endosomes. Antibodies to LAMP1 stained many fewer vesicles and these vesicles were distributed differently than the vesicles stained with antibodies to pSMAD1 or 2 (not shown). Antibodies to Rab5b and EEA1 stained vesicles with a distribution
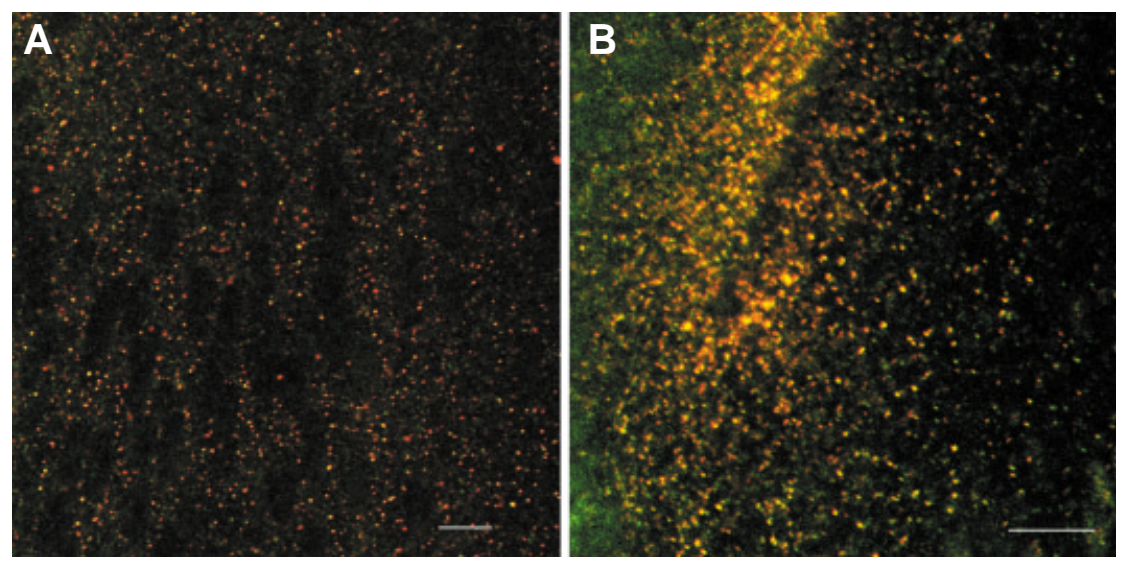

Fig. 9. Co-staining of vesicles in the fiber cells of $\mathbf{P 2}$ mouse lenses. (A) Antibodies to pSMAD1 (red) and Rab5b (green). (B) Antibodies to pSMAD1 (red) and EEA1 (green). Scale bars represent $10 \mu \mathrm{m}$. 
Fig. 10. Staining of $A / k 3^{\text {flox/flox }} \mathbf{P} 2$ mouse lenses with antibodies to pSMAD1. (A) A Cre- lens showing abundant pSMAD1-stained vesicles in the epithelial cells and superficial fiber cells. (B) $\mathrm{A} C r \mathrm{Cr}^{+}$lens from a littermate of the animal whose lens is shown in (A). Few pSMAD1-positive vesicles are present in the epithelial and superficial fiber cells. Both lenses had similar numbers of pSMAD1-positive vesicles in the deeper fiber cells. Nuclei are stained with TOTO-1. The scale bar represents $10 \mu \mathrm{m}$
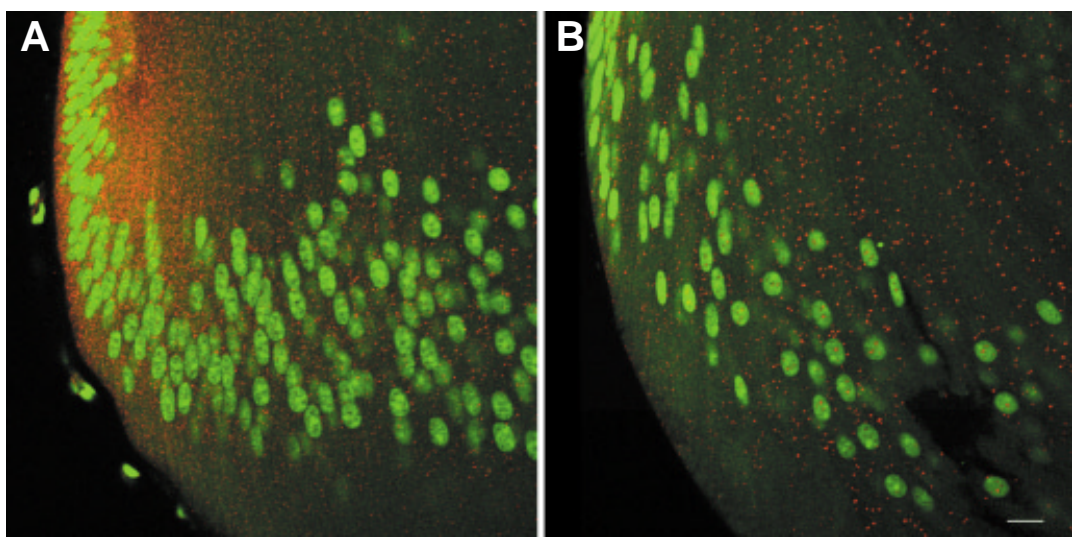

that resembled that seen for the pSMADs (Fig. 9). Doublelabeling showed that both EEA1 and Rab5b co-localized with pSMAD1 (Fig. 9). Few Rab5b- or EEA1-positive endosomes were detected that were not also stained for pSMADs.

Treatment of cultured cells with TGF $\beta$ causes pSMADs to associate with endosomes and endosome formation is required for TGF $\beta$ signaling in cultured epithelial and endothelial cells (Hayes et al., 2002, Panopoulou et al., 2002). Although our studies did not test whether endosomes are required for transmitting BMP signals in the lens in vivo, we did determine whether the distribution of pSMAD1-positive endosomes was altered in lenses lacking the BMP receptor Alk3. Lenses of newborn $A / k 3^{\text {flox/flox }}$ mice (P2) were fixed, sectioned and stained with antibody to pSMAD1 and with the fluorescent nucleic acid dye, TOTO-1. Cre ${ }^{+}$mice had sharply reduced numbers of pSMAD1positive endosomes in the epithelial and fiber cells near the lens equator, compared to their Cre- littermates (Fig. 10). The number of pSMAD1-positive endosomes appeared similar in the deeper fiber cells in the lenses of both genotypes. These data suggest that the association of pSMADs with endosomes is involved in BMP signaling. Further studies are required to determine whether endosomes play an essential role in BMP signaling in the lens.

\section{The development of lenses lacking TGF $\beta R I I$}

The lens fiber cells of transgenic mice in which dominantnegative type I or type II TGF $\beta$ receptors are over expressed develop morphological defects and degenerate at later stages of their differentiation (de longh et al., 2001b). TGF $\beta$ receptors signal through SMAD2 and we showed that PSMAD2 is present in the nuclei of elongating and maturing fiber cells. Therefore, we

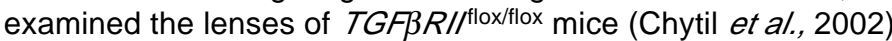
in which Cre recombinase was expressed. Based on the previous results, one would predict that these lenses would show defects in fiber cells differentiation and changes in the distribution of

Fig. 11. TGF $\beta$ signaling is not required for lens development. (A) Section of an eye from a P2 TFG $\beta R / I^{\text {flox }}$ flox, $\mathrm{Cre}^{+}$mouse showing normal lens and eye morphology. (B) A darkfield photograph of lenses from one-month-old $\mathrm{Cre}^{-}$and $\mathrm{Cre}^{+}$ TFG $\beta R / I^{\text {floxflox }}$ mice, showing that both were transparent. The only observable difference was that $\mathrm{Cre}^{+}$ lenses were sometimes slightly smaller than Cre- lenses. The slight peripheral opacities occurred during the preparation of the lenses for photography. (C) Graph showing the fluorescence intensity generated by PCR amplification of $\beta$-actin or TGF $\beta R I I$ cDNA using a BioRad iCycler. The circles show where the amplification products crossed the threshold for quantification. The red circle denotes the $\beta$-actin PCR products from both $\mathrm{Cre}^{-}$and $\mathrm{Cre}^{+}$lenses, the black circle identifies the TGF $\beta R$ II PCR products from Cre-lenses, and the blue circle denotes the TGF $\beta R / l$ products from

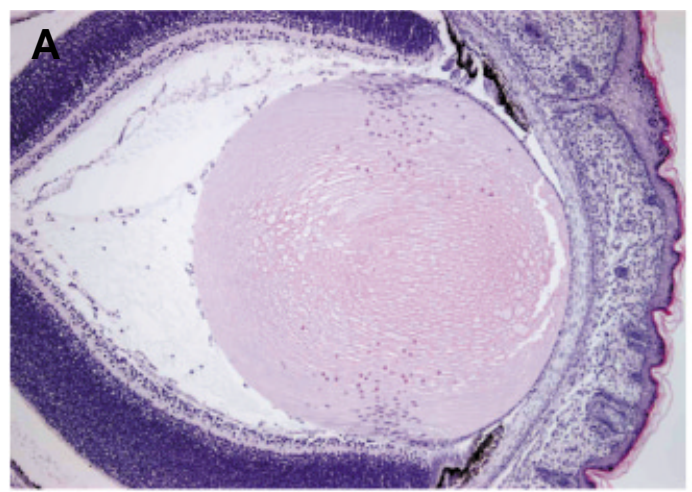

C

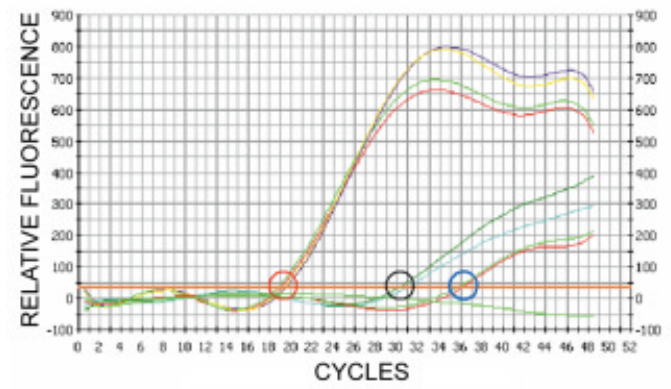

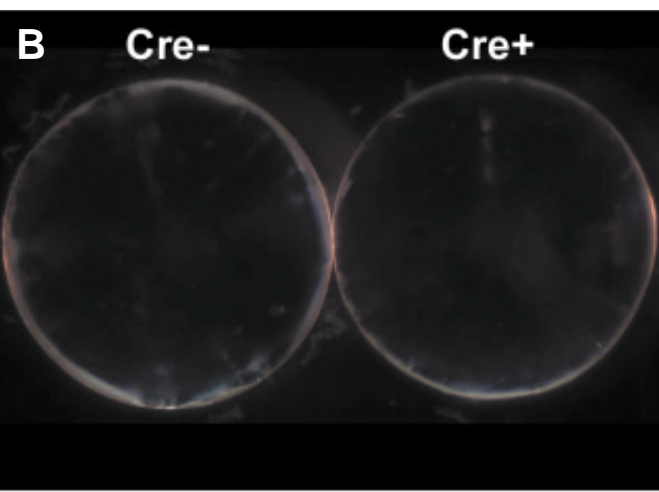

D

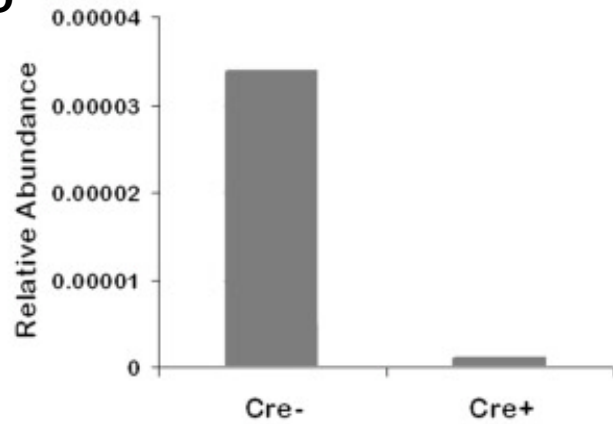

Cre ${ }^{+}$lenses. (D) Graph showing the abundance of the TGFBRII PCR products from Cre ${ }^{-}$and $C_{r}{ }^{+}$lenses, relative to the amount of $\beta$-actin PCR product. 

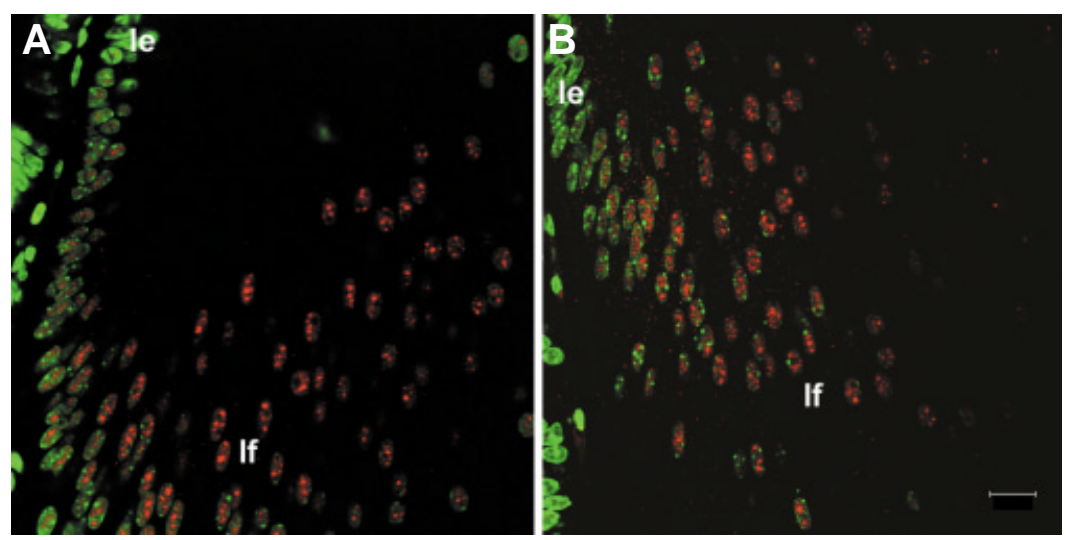

Fig. 12. Staining of TFG $\beta R$ II flox/flox $P 2$ mouse lenses with antibody to pSMAD2 (A) Equatorial region of a Cre- lens. (B) Equatorial region of a Cre lens of a littermate of the animal whose lens is shown in (A). Nuclei are stained with TOTO-1. Scale bar represents $10 \mu \mathrm{m}$; le, lens epithelium; If, lens fibers.

pSMAD2 in lens fiber cells, caused by disruption of endogenous TGF $\beta$ signaling.

P2 mice that were TGF $\beta R / /^{\text {flox/flox }}, \mathrm{Cre}^{+}$had normal-appearing eyes with lenses that showed normal fiber cell morphology (Fig. $11 \mathrm{~A})$. The lenses of adult TGF $R / /_{/ \text {flox/flox }}, \mathrm{Cre}^{+}$lenses were transparent, but sometimes appeared slightly smaller than their Cre-littermates (Fig. 11B). To confirm that the conditional TGFBRII allele had been disrupted by Cre-mediated recombination, we used quantitative real-time PCR to measure the level of TGF $\beta R$ II transcripts in TGF $R$ R/flox/flox Cre $^{+}$or Cre- lenses. Lenses that did not express Cre had low but detectable levels of mRNA for TGF $\beta$ RII, compared to the $\beta$-actin standard. In three trials, Cre $^{+}$ lenses expressed a maximum of $3 \%$ of the TGF $\beta$ RII mRNA level found in the Cre- lenses (Fig. 11 C,D).

To determine whether TGF $\beta$ signaling contributed to the pSMAD2 staining seen in lens fiber cells, we stained sections of TGF $R$ R//flox/flox $\mathrm{Cre}^{-}$or $\mathrm{Cre}^{+}$lenses with an antibody to pSMAD2. Figure 12 shows that nuclear pSMAD2 staining first appeared in elongating cells near the lens equator. Staining increased during fiber cell differentiation and was present in a punctate pattern in the nuclei. Vesicles that stained for PSMAD2 were present in the fiber cell cytoplasm, although not in the abundance seen in other preparations. The intensity and distribution of pSMAD2 staining was similar whether Cre was expressed in the lens or not. These results indicate that signaling by TGF $\beta$ accounts for little or none of the pSMAD2 staining seen in lens fiber cells.

\section{Discussion}

Members of the TGF $\beta$ superfamily play important roles in many tissues at all stages of embryonic and postnatal development. Even if one considers only members of the BMP family, the importance of these molecules is evident. For example, BMP signaling is required for the viability of the preimplantation embryo (Zhao 2003), patterning the embryonic mesoderm (Zhao 2003), establishment of the dorsalventral axis in the invertebrate and vertebrate embryo (Shimmi and O'Connor 2003), early and later stages of hematopoiesis (Zhang and Evans 1996), neural crest cell formation (Tribulo et al., 2003), kidney development (Godin et al., 1999), heart development (Delot et al., 2003), limb patterning (Soshnikova et al., 2003), chondrogenesis and skeletogenesis (Chimal-Monroy et al., 2003), tooth development (Jernvall and Thesleff 2000), inner ear formation (Chang et al., 2002b), several aspects of eye development (see Introduction and below) and normal bone development and remodeling (Winkler etal., 2003).

Previous studies showed that lens and eye development is disrupted in embryos lacking BMP4 or BMP7 (Dudley et al., 1995, Furuta and Hogan 1998, Godin et al., 1999, Jena et al., 1997, Luo et al., 1995, Solursh et al., 1996, Wawersik et al., 1999). Analysis of these defects was complicated by the fact that BMP4 null embryos die just as eye development is beginning and because the phenotype of BMP7 knockouts is variable, with some embryos having normal eyes and others lacking eyes entirely. The receptors that mediate signaling by BMP 4 and 7 in the lens placode are not known, although Alk2 protein and Alk3 mRNA are present at the time of lens formation (Obata et al., 1999, Yoshikawa et al., 2000).

In our studies, disruption of the floxed $A / k 3$ gene using a Cre transgene that is expressed early in lens placode formation did not prevent lens formation, since lenses were always present at later stages of development. In several cases, we observed persistence of the lens stalk (similar to Peters anomaly), suggesting that early lens formation was slightly affected by the deletion of $A / k 3$. There are several possibilities that may explain why loss of $A / k 3$ did not recapitulate the lens phenotype of BMP4 or 7 null animals. It is possible that Alk3 does not contribute to lens formation, or that Alk3 is normally involved in lens formation, but signaling through Alk2, which is also expressed in the lens placode, is sufficient to support lens formation in the absence of Alk3. It is also possible that, since Alk3 is expressed before the formation of the lens placode, disruption of the $A / k 3$ gene in the lens placode did not lead to loss of Alk3 mRNA and protein until lens development was already under way. In a previous study, in which the Le-Cre transgene was used to delete the Pax6 gene in the lens placode, the expression of the Cre transgene also commenced after expression of Pax6 had begun, yet lens formation was prevented (Ashery-Padan etal., 2000). This may indicate that Alk3 is not required for lens formation or that Alk3 mRNA and protein are more stable or required at a lower level than Pax6.

It is also possible that both $A / k 3$ alleles were not disrupted in all cells of the lens placode. While our experience with the efficiency of deletion of $T G F \beta R / /$ floxed alleles and the uniformity of the $A / k 3$ phenotype seen at later stages of development does not suggest incomplete inactivation of the targeted genes, this possibility cannot be ruled out, especially at early stages of eye development, soon after Cre expression begins. Demonstrating the inactivation of a target gene at early stages of development would require sensitive in situ hybridization or laser capture microdissection, analyses that were not performed in this study.

BMP signaling is also important in later lens development. Over expression of a dominant-negative form of $B M P R-1 B$ (Alk6) using promoters that drive transgene expression in the lens epithelium or early fiber cells inhibited primary fiber cell formation selectively on the nasal side of the lens (Faber et al., 2002). Since the type II BMP receptor was uniformly expressed in the lens at this stage, these authors suggested that the ligand that activates signaling through Alk6 is asymmetrically distributed in the nasal 
part of the eye. These authors did not indicate whether later stages of fiber cell differentiation were affected in the transgenic lenses. Increasing the level of the BMP antagonist noggin in the eye also inhibited primary fiber cell elongation (Belecky-Adams et al., 2002, Faber et al., 2002), although elongation later recovered (Belecky-Adams et al., 2002). Noggin also inhibited the ability of vitreous humor to stimulate the elongation of lens epithelial cells in an in vitroassay of lens fiber cell formation (Belecky-Adams et al., 2002). In these studies, phosphorylated SMAD1 was detected in the fiber cell nuclei of both chicken and mouse lenses (BeleckyAdams et al., 2002, Faber et al., 2002).

The present studies show that signaling through $A / k 3$ contributes to the later development of lens epithelial and fiber cells. At E13.5, lenses lacking $A / k 3$ were smaller than wild type, with thinner lens epithelia. $A / k 3$ null lenses were smaller than normal throughout development. Neonatal lenses lacking Alk3 had gaps in the lens epithelium, especially adjacent to the ciliary epithelium. This may indicate that the ligand that activates Alk3 in the lens epithelium is produced by the ciliary epithelial cells, or that cells in this region of the lens epithelium are more dependent on signaling through $A / k 3$. These observations indicate that Alk3 signaling is needed to support the normal rate of lens cell proliferation, to maintain the viability of epithelial cells, or both. Preliminary examination of BrdU and TUNEL labeling at early postnatal stages did not reveal major differences in the rate of cell proliferation or death in $A / k 3$ null and wild type lenses. Further quantitative analyses are required to account for the small size and slower growth of lenses lacking A/k3.

In addition to the defects in the lens epithelium, $A / \mathrm{k} 3$ null lens fiber cells became vacuolated and began to degenerate by the first postnatal week. This could reflect abnormalities in the fiber cells caused by deficiencies in the lens epithelium, direct effects of Alk3 on the differentiation of the fiber cells, or both. In studies in progress, we found altered levels of the oncogene c-Ski in the epithelial and fiber cells of $A / k 3$ null lenses. c-Ski is a transcriptional repressor that plays an important role in TGF $\beta$-mediated gene expression (Akiyoshi et al., 1999, Xu et al., 2000). Since c-Ski levels are altered and pSMAD1 levels are decreased in $A / k 3$ null lens fiber cells, it is likely that Alk3 directly affects the differentiation of both epithelial and fiber cells.

The lens defects seen in $A / k 3$ null lenses were accompanied by alterations in other cells in the eye. Large numbers of mesenchymal cells were present around the hyaloid vasculature in the vitreous body. In the postnatal eye, these cells coalesced to form a dense plaque at the posterior of the lens. Numerous mesenchymal cells also filled the space normally occupied by the anterior chamber and the formation of the corneal endothelium appeared to be inhibited. Since the transgenic mice only express Cre in the lens, ocular surface epithelia and pancreas (AsheryPadan et al., 2000), the aberrant cells in the vitreous and anterior chambers must be responding changes in Alk3-dependent signals from these tissues. Signals from the lens are required for the normal development of the corneal endothelium (Beebe and Coats 2000) and the ciliary epithelium (Thut etal., 2001). Therefore, our results suggest that Alk3 is required for the proper production of signals that normally regulate the migration and/or proliferation of mesenchyme cells within the eye.

The availability of lenses with targeted deletion of the components of specific signaling pathways opens up possibilities for study that are not found in most other tissues during development. From early stages of lens development, lens cells can be isolated free of other cell types. Therefore, examining the mRNA expression profiles of lenses that lack a specific receptor or intracellular mediator will permit detailed analysis of the genes that are directly or indirectly regulated by specific signaling pathways.

Our data suggest that, in addition to BMPs, at least one additional member of the TGF $\beta$ superfamily activates signaling in lens fiber cells. Follistatin, a binding protein that prevents activins from interacting with their receptors, cooperated with the BMP antagonist noggin to block the elongation of cultured chicken embryo lens epithelial cells. In addition, antibodies to pSMAD2 localized to the nuclei of chicken embryo and mouse lens fiber cells. Since BMPs are not known to cause the phosphorylation of SMAD2, these studies indicate that another member of the TGF $\beta$ superfamily is signaling in lens fiber cells. Lenses that lacked the type II TGF $\beta$ receptor developed normally and had normal levels of pSMAD2 staining in fiber cell nuclei. Therefore, the ligand responsible for the pSMAD2 staining is not likely to be one of the TGF $\beta$ s. Several activins are expressed in the developing retina (Belecky-Adams et al., 1999), activins signal through SMAD2, and activin signaling is inhibited by follistatin. Activins are, therefore, potential candidates for this ligand. However, although most or all activin genes have been deleted by homologous recombination, we are not aware of genetic evidence linking activin signaling with lens development.

In addition to being present in the nuclei of elongating lens fiber cells, phosphorylated SMAD1 and 2 localized to endosomes in the cytoplasm of epithelial and fiber cells. Endosomal pSMAD1 decreased markedly in lenses lacking $A / k 3$, showing that signaling through this receptor contributes to the generation of endosomal pSMAD1. Endosome formation appears to play an essential role in signaling by TGF $\beta$ receptors (Hayes et al., 2002, Panopoulou etal., 2002). However, from our data we cannot say that endosomes are important for BMP signaling, only that there is an association between BMP signaling and PSMAD localization to endosomes. It is worth noting that intermediates of the Raf/MEK/ERK signaling pathway also localize to endosomes and that endosomal localization contributes to or is required for signaling through this pathway (Delcroix etal., 2003, Pennock and Wang 2003, Teis and Huber 2003, Teis et al., 2002, Ye et al., 2003). In preliminary studies, we co-localized pERK with pSMAD1 on endosomes in lens fiber cells ( $\mathrm{Yu}$, Guo and Beebe, unpublished), showing that endosomes are a common component of Raf/MEK/ERK and SMAD signaling in the lens. We believe that further study of the role of endosomes in growth factor signaling in the lens is warranted. Although pSMAD1 and 2 staining was not prominent in the nuclei of lens epithelial cells, endosomes containing pSMAD1 and 2 were abundant in the epithelial cell cytoplasm. The transport of pSMADs from endosomes to the nucleus could be an important control step in signaling by TGF $\beta$ family members. It is also possible that pSMADs are present in the nuclei of lens epithelial cells, although at lower levels than in the nuclei of fiber cells. This possibility is supported by the observation that lens epithelial cells were abnormal in $A / k 3$ null lenses. Therefore, although pSMADs are not as abundant in the nuclei of epithelial cells as in elongating fiber cells, BMP signaling probably occurs there.

The normal appearance of lenses lacking functional TGF $\beta$ RII was initially a surprise to us. In a previous study, dominantnegative (kinase-deficient) type I or type II TGF $\beta$ receptors were 
over expressed in the lens fiber cells of transgenic animals (de longh et al., 2001b). These lenses developed nuclear cataracts and showed attenuated fiber cell elongation, disrupted fiber cell differentiation and eventual fiber cell degeneration. In the present study, analysis of three different sets of $T G F \beta R / /$ flox/flox, $\mathrm{Cre}^{+}$ lenses detected a maximum of $3 \%$ of the level of TGF $\beta R I I$ mRNA found in $\mathrm{Cre}^{-}$littermates (in two tests no TGF $\beta$ RII mRNA was detected in the $\mathrm{Cre}^{+}$lenses), suggesting that a maximum of $6 \%$ of the cells contained one functional TGFBR//allele. Since there is only a single type II receptor that mediates TGF $\beta$ signaling, we interpret these results to indicate that TGF $\beta$ is not required for normal lens growth or differentiation. It is possible that over expression of kinase-deficient TGF $\beta$ receptors disrupted fiber cell differentiation by a non-specific mechanism, possibly related to the excessive expression of an integral membrane protein, rather than by interrupting TGF $\beta$ signaling. If this is correct, careful reevaluation of other studies in which other transmembrane proteins were over expressed in lens fibers may be warranted.

\section{Matherials and Methods}

Alk3 $3^{\text {flox/flox }}$ (Mishina et al., 2002) or TGFBR/flox/flox (Chytil et al., 2002) mice were mated with Le-Cre transgenic mice (Ashery-Padan et al., 2000) and offspring were crossed to generate litters that contained animals that were homozygous for the floxed alleles and $\mathrm{Cre}^{-}$or $\mathrm{Cre}^{+}$. Mice were never created that were homozygous for the LeCre transgene. Mice were genotyped by PCR amplification of genomic DNA using primers that were specific for Cre recombinase or the wild type or floxed alleles of $A / k 3$ and TGFBRI/ (Chytil et al., 2002, Mishina et al., 2002). Pregnant females or postnatal mice were injected with a 10:1 molar combination of BrdU and FdU (50 $\mu \mathrm{g} \mathrm{BrdU/kg} \mathrm{body} \mathrm{weight)} \mathrm{one} \mathrm{hour} \mathrm{before} \mathrm{sacrifice.} \mathrm{For} \mathrm{BrdU} \mathrm{or}$ TUNEL staining, embryos or eyes were fixed overnight in $10 \%$ neutral buffered formalin, embedded in paraffin, sectioned at $4 \mu \mathrm{m}$, de-waxed and stained with anti-BrdU antibody (DAKO) or using the ApopTag Peroxidase In situ Apoptosis Detection Kit (Serologicals Corp.).

For confocal microscopy, chicken embryos or mouse pups were killed at E7 or P2-P5, respectively, lenses were removed, embedded in $4 \%$ agarose and sectioned at $100 \mu \mathrm{m}$ in a tissue slicer (EM Sciences), as described previously (Beebe et al., 2001, Belecky-Adams et al., 2002). Antigen colocalization using rabbit polyclonal primary antibodies was performed by staining tissues overnight in the first primary antibody (diluted in $0.5 \%$ Triton $\mathrm{X}-100,10 \%$ normal goat serum in PBS), washing the sections in $0.5 \%$ Tween-20 in PBS, and then staining overnight using the first secondary antibody (secondary antibodies were Alexa488, 546, 563, or 633 anti-rabbit IgG, Molecular Probes). After thorough washing to remove excess secondary antibody, tissue slices were fixed for one hour in $10 \%$ neutral buffered formalin and washed in Tween-PBS. Sections were then exposed to the second primary antibody overnight, washed, treated with the second secondary antibody overnight or for three hours, washed and examined using a Zeiss 410 or 510 confocal microscope. In every case, control slices were included in which the second primary antibody was omitted. These sections were examined to assure that there was no detectable binding of the second secondary antibody to the first primary antibody. In no case was crossbinding detected. The primary antibodies used were specific for Rab5b (Santa Cruz Biotechnology), EEA1 (Calbiochem), phospho-SMAD1 and phospho-SMAD2 (Cell Signaling). TOTO-1 $(0.1 \mu \mathrm{g} / \mathrm{ml})$ was used to stain nuclei in some preparations (Molecular Probes)

The elongation of chicken embryo lens epithelial cells was measured using a microscope with a digital readout of focal position, as described previously (Belecky-Adams etal., 2002). Recombinant noggin and follistatin were obtained from R\&D Systems.

Expression of TGFBR// transcripts was determined by TaqMan PCR using a Bio-Rad iCycler. One $\mu \mathrm{g}$ of total lens RNA was used to synthesize
cDNA in a standard reaction and one $\mu$ of cDNA was used as the template for PCR amplification of TGF $\beta R / /$ and $\beta$-actinsequences using 10 picomole of each primer in a $50 \mu \mathrm{l}$ reaction mixture. PCR reactions $\left(95^{\circ} \mathrm{C} 3 \mathrm{~min}\right.$, then 50 cycles of $95^{\circ} \mathrm{C} 15 \mathrm{~s}, 60^{\circ} \mathrm{C} 1 \mathrm{~min}$ ) were examined by gel electrophoresis after TaqMan analysis, to confirm the identity of the PCR products. Primer sequences were:

$\beta$-actin 5': 5'-GCCTCACTGTCCACCTTCCA-3';

$\beta$-actin 3': 5'-AAACGCAGCTCAGTAACAGTCC-3';

$\beta$-actin TaqMan: 6-FAM-5'-CCGGACTCATCGTACTCCTGCTTGCTG-3'; TGFRR//5': 5'-TTTGCGACGTGAGACTGTCCA-3';

TGFBR//3': 5'-GTGGCAAACCGTCTCCAGAGT-3';

TGFBR//TaqMan: 6-FAM-5'-TTGCGACAACCAGAAGTCCTGCATGAGC-3'

\section{Acknowledgements}

The authors thank Dr. Yuji Mishina for providing the Alk3 flox mice and Dr. Peter Gruss, in whose laboratory the Le-Cre mice were generated. Belinda McMahan and Jean Jones provided valuable technical assistance. Research was supported by grant EY04853 from the USNational Institutes of Health, a research grant from The Israel Science Foundation (401/02) to RA-P., and an unrestricted grant from Research to Prevent Blindness and Core Grant EY02687 to the Department of Ophthalmology and Visual Sciences.

\section{References}

ADLER, R., and T. L. BELECKY-ADAMS. 2002. The role of bone morphogenetic proteins in the differentiation of the ventral optic cup. Development 129: 3161-71.

AKIYOSHI, S., H. INOUE, J.-I. HANAI, K. KUSANAGI, N. NEMOTO, K. MIYAZONO, and M. KAWABATA. 1999. C-ski acts as a transcriptional co-repressor in transforming growth factor-beta signaling through interaction with smads. J. Biol. Chem. 274: 35269-35277.

ASHERY-PADAN, R., T. MARQUARDT, X. ZHOU, and P. GRUSS. 2000. Pax6 activity in the lens primordium is required for lens formation and for correct placement of a single retina in the eye. Genes Dev 14: 2701-2711.

BASSNETT, S. 2002. Lens organelle degradation. Experimental Eye Research74: 1 6.

BASSNETT, S., and D. C. BEEBE. 1992. Coincident loss of mitochondria and nucle during lens fiber cell differentiation. Dev Dyn 194: 85-93.

BASSNETT, S., and P. A. WINZENBURGER. 2003. Morphometric analysis of fibre cell growth in the developing chicken lens. Exp Eye Res 76: 291-302.

BEEBE, D. C., and J. M. COATS. 2000. The lens organizes the anterior segment: Specification of neural crest cell differentiation in the avian eye. Dev Bio/220: 424431

BEEBE, D. C., M. H. SILVER, K. S. BELCHER, J. J. VAN WYK, M. E. SVOBODA, and P. S. ZELENKA. 1987. Lentropin, a protein that controls lens fiber formation, is related functionally and immunologically to the insulin-like growth factors. Proc Natl Acad Sci USA 84: 2327-30.

BEEBE, D. C., O. VASILIEV, J. GUO, Y. B. SHUI, and S. BASSNETT. 2001. Changes in adhesion complexes define stages in the differentiation of lens fiber cells. Invest Ophthalmol Vis Sci42: 727-734.

BELECKY-ADAMS, T., and R. ADLER. 2001. Developmental expression patterns of bone morphogenetic proteins, receptors, and binding proteins in the chick retina $\checkmark$ Comp Neuro/430: 562-72.

BELECKY-ADAMS, T. L., R. ADLER, and D. C. BEEBE. 2002. Bone morphogenetic protein signaling and the initiation of lens fiber cell differentiation. Development 129: $3795-802$

BELECKY-ADAMS, T. L., D. SCHEURER, and R. ADLER. 1999. Activin family members in the developing chick retina: Expression patterns, protein distribution, and in vitro effects. Dev Bio/210: 107-23.

BENEDEK, G. B., J. PANDE, G. M. THURSTON, and J. I. CLARK. 1999. Theoretical and experimental basis for the inhibition of cataract. Prog Retin Eye Res 18: 391 402.

BOTCHKAREV, V. A., N. V. BOTCHKAREVA, M. NAKAMURA, O. HUBER, K. FUNA, R. LAUSTER, R. PAUS, and B. A. GILCHREST. 2001. Noggin is required for induction of the hair follicle growth phase in postnatal skin. Faseb J15: 2205-14. 
CHAMBERLAIN, C. G., and J. W. MCAVOY. 1989. Induction of lens fibre differentiation by acidic and basic fibroblast growth factor (fgf). Growth Factors 1: 125-34.

CHANG, H., C. W. BROWN, and M. M. MATZUK. 2002a. Genetic analysis of the mammalian transforming growth factor-\{beta\} superfamily. Endocr Rev 23: 787823.

CHANG, W., P. TEN DIJKE, and D. K. WU. 2002b. Bmp pathways are involved in otic capsule formation and epithelial-mesenchymal signaling in the developing chicken inner ear. Dev Bio/251: 380-394.

CHIMAL-MONROY, J., J. RODRIGUEZ-LEON, J. A. MONTERO, Y. GANAN, D. MACIAS, R. MERINO, and J. M. HURLE. 2003. Analysis of the molecular cascade responsible for mesodermal limb chondrogenesis: Sox genes and bmp signaling. Dev Bio/257: 292-301.

CHOW, R. L., G. D. ROUX, M. ROGHANI, M. A. PALMER, D. B. RIFKIN, D. A MOSCATELLI, and R. A. LANG. 1995. Fgf suppresses apoptosis and induces differentiation of fibre cells in the mouse lens. Development 121: 4383-93.

CHYTIL, A., M. A. MAGNUSON, C. V. WRIGHT, and H. L. MOSES. 2002. Conditional inactivation of the tgf-beta type ii receptor using cre:Lox. Genesis 32: 73-5.

DE IONGH, R. U., C. GORDON-THOMSON, C. G. CHAMBERLAIN, A. M. HALES, and J. W. MCAVOY. 2001a. Tgfbeta receptor expression in lens: Implications for differentiation and cataractogenesis. Exp Eye Res 72: 649-59.

DE IONGH, R. U., F. J. LOVICU, P. A. OVERBEEK, M. D. SCHNEIDER, J. JOYA E. D. HARDEMAN, and J. W. MCAVOY. 2001b. Requirement for tgfbeta receptor signaling during terminal lens fiber differentiation. Development 128 : 3995-4010.

DELAYE, M., and A. TARDIEU. 1983. Short-range order of crystallin proteins accounts for eye lens transparency. Nature 302: 415-417.

DELCROIX, J. D., J. S. VALLETTA, C. WU, S. J. HUNT, A. S. KOWAL, and W. C. MOBLEY. 2003. Ngf signaling in sensory neurons: Evidence that early endosomes carry ngf retrograde signals. Neuron 39: 69-84.

DELOT, E. C., M. E. BAHAMONDE, M. ZHAO, and K. M. LYONS. 2003. Bmp signaling is required for septation of the outflow tract of the mammalian heart. Development 130: $209-220$

DERYNCK, R., and Y. E. ZHANG. 2003. Smad-dependent and smad-independent pathways in tgf-beta family signalling. Nature 425: 577-84.

DUDLEY, A. T., K. M. LYONS, and E. J. ROBERTSON. 1995. A requirement for bone morphogenetic protein-7 during development of the mammalian kidney and eye. Genes Dev 9: 2795-807.

FABER, S. C., P. DIMANLIG, H. P. MAKARENKOVA, S. SHIRKE, K. KO, and R. A. LANG. 2001. Fgf receptor signaling plays a role in lens induction. Development 128 : 4425-4438.

FABER, S. C., M. L. ROBINSON, H. P. MAKARENKOVA, and R. A. LANG. 2002. Bmp signaling is required for development of primary lens fiber cells. Development 129 : 3727-3737.

FUHRMANN, S., E. M. LEVINE, and T. A. REH. 2000. Extraocular mesenchyme patterns the optic vesicle during early eye development in the embryonic chick. Development 127: 4599-609.

FURUTA, Y., and B. L. M. HOGAN. 1998. Bmp4 is essential for lens induction in the mouse embryo. Genes Dev12: 3764-75.

GODIN, R. E., E. J. ROBERTSON, and A. T. DUDLEY. 1999. Role of bmp family members during kidney development. Int J Dev Bio/43: 405-11.

GOODENOUGH, D. A. 1992. The crystalline lens. A system networked by gap junctional intercellular communication. Semin Cell Bio/3: 49-58.

GOUMANS, M. J., and C. MUMMERY. 2000. Functional analysis of the tgfbeta receptor/smad pathway through gene ablation in mice. Int J Dev Bio/44: 253-65.

HAYES, S., A. CHAWLA, and S. CORVERA. 2002. Tgf \{beta\} receptor internalization into eea1-enriched early endosomes: Role in signaling to smad2. J. Cel/ Biol. 158: 1239-1249.

JENA, N., C. MARTIN-SEISDEDOS, P. MCCUE, and C. M. CROCE. 1997. Bmp7 null mutation in mice: Developmental defects in skeleton, kidney, and eye. Exp Cel/Res 230: $28-37$

JERNVALL, J., and I. THESLEFF. 2000. Reiterative signaling and patterning during mammalian tooth morphogenesis. Mech Dev 92: 19-29.

KOBIELAK, K., H. A. PASOLLI, L. ALONSO, L. POLAK, and E. FUCHS. 2003. Defining bmp functions in the hair follicle by conditional ablation of bmp receptor ia. J. Cell Biol. 163: 609-623.
KULESSA, H., G. TURK, and B. L. HOGAN. 2000. Inhibition of bmp signaling affects growth and differentiation in the anagen hair follicle. EMBO J19: 6664-74.

KUSHMERICK, C., S. J. RICE, G. J. BALDO, H. C. HASPEL, and R. T. MATHIAS. 1995. Ion, water and neutral solute transport in xenopus oocytes expressing frog lens mip. Exp Eye Res 61: 351-62.

KUSZAK, J. R. 1995. The development of lens sutures. Progress in Retinal and Eye Research 14: 567-592

KUWABARA, T., and M. IMAIZUMI. 1974. Denucleation process of the lens. Invest Ophthalmo/13: 973-81.

LIU, J., S. WILSON, and T. REH. 2003. Bmp receptor $1 \mathrm{~b}$ is required for axon guidance and cell survival in the developing retina. Dev Bio/256: 34-48.

LUO, G., C. HOFMANN, A. L. BRONCKERS, M. SOHOCKI, A. BRADLEY, and G. KARSENTY. 1995. Bmp-7 is an inducer of nephrogenesis, and is also required for eye development and skeletal patterning. Genes Dev 9: 2808-20.

MACPHERSON, D., J. SAGE, D. CROWLEY, A. TRUMPP, R. T. BRONSON, and T. JACKS. 2003. Conditional mutation of rb causes cell cycle defects without apoptosis in the central nervous system. Mol. Cell. Biol. 23: 1044-1053.

MERRIMAN-SMITH, R., P. DONALDSON, and J. KISTLER. 1999. Differential expression of facilitative glucose transporters glut1 and glut3 in the lens. Invest Ophthalmol Vis Sci40: 3224-30.

MISHINA, Y. 2003. Function of bone morphogenetic protein signaling during mouse development. Front Biosci8: D855-69.

MISHINA, Y., M. C. HANKS, S. MIURA, M. D. TALLQUIST, and R. R. BEHRINGER 2002. Generation of bmpr/alk3 conditional knockout mice. Genesis 32: 69-72.

MISHINA, Y., A. SUZUKI, N. UENO, and R. BEHRINGER. 1995. Bmpr encodes a type i bone morphogenetic protein receptor that is essential for gastrulation during mouse embryogenesis. Genes Dev. 9: 3027-3037.

OBATA, H., Y. KAJI, H. YAMADA, M. KATO, T. TSURU, and H. YAMASHITA. 1999 Expression of transforming growth factor-beta superfamily receptors in rat eyes. Acta Ophthalmol Scand 77: 151-6.

PANOPOULOU, E., D. J. GILLOOLY, J. L. WRANA, M. ZERIAL, H. STENMARK C. MURPHY, and T. FOTSIS. 2002. Early endosomal regulation of smaddependent signaling in endothelial cells. J. Biol. Chem. 277: 18046-18052.

PATTERSON, G. I., and R. W. PADGETT. 2000. Tg beta-related pathways. Roles in caenorhabditis elegans development. Trends Genet 16: 27-33.

PENNOCK, S., and Z. WANG. 2003. Stimulation of cell proliferation by endosomal epidermal growth factor receptor as revealed through two distinct phases of signaling. Mol. Cell. Biol. 23: 5803-5815.

RAFFERTY, N. S., and K. A. RAFFERTY. 1981. Cell population kinetics of the mouse lens epithelium. J. of Cellular Physiology 107: 309-315.

RENEKER, L. W., D. W. SILVERSIDES, K. PATEL, and P. A. OVERBEEK. 1995 Tgf alpha can act as a chemoattractant to perioptic mesenchymal cells in developing mouse eyes. Development 121: 1669-80.

ROBINSON, M. L., L. A. MACMILLAN-CROW, J. A. THOMPSON, and P. A OVERBEEK. 1995a. Expression of a truncated fgf receptor results in defective lens development in transgenic mice. Development 121: 3959-67.

ROBINSON, M. L., P. A. OVERBEEK, D. J. VERRAN, W. E. GRIZZLE, C. R. STOCKARD, R. FRIESEL, T. MACIAG, and J. A. THOMPSON. 1995b. Extracellular fgf- 1 acts as a lens differentiation factor in transgenic mice. Development 121: 505-14.

SAIKA, S., C. Y. LIU, M. AZHAR, L. P. SANFORD, T. DOETSCHMAN, R. L. GENDRON, C. W. KAO, and W. W. KAO. 2001. Tgfbeta2 in corneal morphogenesis during mouse embryonic development. Dev Bio/240: 419-32.

SAKUTA, H., R. SUZUKI, H. TAKAHASHI, A. KATO, T. SHINTANI, S. IEMURA, T. S. YAMAMOTO, N. UENO, and M. NODA. 2001. Ventroptin: A bmp-4 antagonist expressed in a double-gradient pattern in the retina. Science 293: 111-5.

SANFORD, L., I. ORMSBY, A. GITTENBERGER-DE GROOT, H. SARIOLA, R. FRIEDMAN, G. BOIVIN, E. CARDELL, and T. DOETSCHMAN. 1997. TGFbeta2 knockout mice have multiple developmental defects that are non-overlapping with other TGFbeta knockout phenotypes. Development 124: 2659-2670.

SHESTOPALOV, V. I., and S. BASSNETT. 2000. Expression of autofluorescent proteins reveals a novel protein permeable pathway between cells in the lens core. J Cell Sci113: 1913-1921.

SHIMMI, O., and M. B. O'CONNOR. 2003. Physical properties of tld, sog, tsg and dpp protein interactions are predicted to help create a sharp boundary in bmp 
signals during dorsoventral patterning of the drosophila embryo. Development 130: 4673-4682.

SMITH, W. C. 1999. Tgf beta inhibitors. New and unexpected requirements in vertebrate development. Trends Genet 15: 3-5.

SOLURSH, M., R. M. LANGILLE, J. WOOD, and T. K. SAMPATH. 1996. Osteogenic protein-1 is required for mammalian eye development. Biochem Biophys Res Commun 218: 438-43.

SOSHNIKOVA, N., D. ZECHNER, J. HUELSKEN, Y. MISHINA, R. R. BEHRINGER, M. M. TAKETO, E. B. CRENSHAW, III, and W. BIRCHMEIER. 2003. Genetic interaction between wnt/\{beta\}-catenin and bmp receptor signaling during formation of the AER and the dorsal-ventral axis in the limb. Genes Dev. 17: 1963-1968.

TEIS, D., and L. A. HUBER. 2003. The odd couple: Signal transduction and endocytosis. Cell Mol Life Sci60: 2020-33.

TEIS, D., W. WUNDERLICH, and L. A. HUBER. 2002. Localization of the mp1mapk scaffold complex to endosomes is mediated by $\mathrm{p} 14$ and required for signal transduction. Dev Cel/3: 803-14.

THUT, C. J., R. B. ROUNTREE, M. HWA, and D. M. KINGSLEY. 2001. A large-scale in situ screen provides molecular evidence for the induction of eye anterior segment structures by the developing lens. Dev Bio/231: 63-76.

TRIBULO, C., M. J. AYBAR, V. H. NGUYEN, M. C. MULLINS, and R. MAYOR, 2003. Regulation of msx genes by a bmp gradient is essential for neural crest specification. Development. 130: 6441-6452.

TROUSSE, F., P. ESTEVE, and P. BOVOLENTA. 2001. Bmp4 mediates apoptotic cell death in the developing chick eye. J Neurosci21: 1292-301.

WALTHER, C., and P. GRUSS. 1991. Pax-6, a murine paired box gene, is expressed in the developing cns. Development 113: 1435-49.
WAWERSIK, S., P. PURCELL, M. RAUCHMAN, A. T. DUDLEY, E. J. ROBERTSON, and R. MAAS. 1999. Bmp7 acts in murine lens placode development. Dev Biol 207: 176-88.

WINKLER, D. G., M. K. SUTHERLAND, J. C. GEOGHEGAN, C. YU, T. HAYES, J. E. SKONIER, D. SHPEKTOR, M. JONAS, B. R. KOVACEVICH, K. STAEHLINGHAMPTON, M. APPLEBY, M. E. BRUNKOW, and J. A. LATHAM. 2003. Osteocyte control of bone formation via sclerostin, a novel bmp antagonist. EMBO J22: 6267-6276.

XU, W., K. ANGELIS, D. DANIELPOUR, M. M. HADDAD, O. BISCHOF, J. CAMPISI, E. STAVNEZER, and E. E. MEDRANO. 2000. Ski acts as a corepressor with smad2 and smad3 to regulate the response to type beta transforming growth factor. Proc Natl Acad Sci USA 97: 5924-9.

YE, H., R. KURUVILLA, L. S. ZWEIFEL, and D. D. GINTY. 2003. Evidence in support of signaling endosome-based retrograde survival of sympathetic neurons. Neuron 39: 57-68.

YOSHIKAWA, S. I., S. AOTA, Y. SHIRAYOSHI, and K. OKAZAKI. 2000. The actr$i$ activin receptor protein is expressed in notochord, lens placode and pituitary primordium cells in the mouse embryo. Mech Dev 91: 439-44.

ZHANG, C., and T. EVANS. 1996. Bmp-like signals are required after the midblastula transition for blood cell development. Dev Genet 18: 267-78.

ZHAO, G. Q. 2003. Consequences of knocking out bmp signaling in the mouse. Genesis 35: 43-56.

ZHAO, S., Q. CHEN, F. C. HUNG, and P. A. OVERBEEK. 2002. Bmp signaling is required for development of the ciliary body. Development 129: 4435-42.

ZWAAN, J., and R. E. KENYON, JR. 1984. Cell replication and terminal differentiation in the embryonic chicken lens: Normal and forced initiation of lens fibre formation. J Embryol Exp Morpho/84: 331-49. 